moth: phenotypic selection in patches with manipulated development time. Evol. Ecol. 12:629-642.

Niijima, K., M. Matsuka, and I. Okada. 1986. Artificial diets for an aphidophagous coccinellid, Harmonia axyridis, and its nutrition. Pp. 37-50 in I. Hodek, ed. Ecology of Aphidophaga. Academia, Prague, and Dr. W. Junk, Dordrecht.

Olszak, R. W. 1986. Suitability of three aphid species as prey for Propylea quatuordecimpunctata. Pp. 51-55 in I. Hodek, ed. Ecology of Aphidophaga. Academia, Prague, and Dr. W. Junk, Dordrecht.

Osawa, N., and T. Nishida. 1992. Seasonal variation in elytral color polymorphism in Harmonia axyridis (the ladybird beetle): the role of non-random mating. Heredity 69:297-307.

Palmer, A. R. 1994. Fluctuating asymmetry analyses: a primer. Pp. 335-364 in T. A. Markow, ed. Developmental instability: its origins and evolutionary implications. Kluwer Academic. Boston, MA.

Palmer, A. R., and C. Strobeck. 1992. Fluctuating asymmetry as a measure of developmental stability: implications of non-normal distributions and power of statistical tests. Acta Zool. Fenn. 191:57-72.

Parsons, P. A. 1992. Fluctuating asymmetry: a biological monitor of environmental and genomic stress. Heredity 68:361-364.

Rayner, J. M. V. 1985. Linear relations in biomechanics: the statistics of scaling functions. J. Zool. 206:415-439.

Roff, D. A. 1997. Evolutionary quantitative genetics. Chapman Hall, New York.

Schlichting, C. D. 1986. The evolution of phenotypic plasticity in plants. Annu. Rev. Ecol. Syst. 17:667-693.

Schluter, D. 1988. Estimating the form of natural selection on a quantitative trait. Evolution 42:221-231.
Schluter, D., T. D. Price, and L. Rowe. 1991. Conflicting selection pressures and life history trade-offs. Proc. R. Soc. Lond. B Biol. Sci. 246:11-17.

Simmons, A. M., and D. A. Roff. 1996. The effect of a variable environment on the genetic correlation structure in the field cricket. Evolution 50:267-275.

Sinervo, B. 1993. The effect of offspring size on physiology and life history: manipulation of size using allometric engineering. BioScience 43:210-218.

Sinervo, B., and A. L. Basolo. 1996. Testing adaptaion using phenotypic manipulations. Pp. 149-186 in M. R. Rose and G. V. Lauder, eds. Adaptation. Academic Press, New York.

Thornhill, R. 1980. Rape in Panorpa scorpionflies and a general rape hypothesis. Anim. Behav. 28:52-59.

Tomlinson, I. P. M., P. W. E. Kearns, and C. J. Vetman. 1995. Nonrandom mating in the two-spot ladybird (Adalia bipunctata): the influence of weight on mating success. Behav. Gen. 25:467474.

Ueno, H. 1994. Genetic estimations for body size characters, development period and development rate in a Coccinellid beetle, Harmonia axyridis. Res. Popul. Ecol. 36:121-124.

Wade, M. J. 1987. Measuring sexual selection. Pp. 197-207 in J. W. Bradbury and M. B. Andersson, eds. Sexual selection: testing the alternatives. Wiley, New York.

Wang, P. C. 1978. Graphical representation of multivariate data. Academic Press, New York.

Wilkinson, L. 1996a. SYSTAT: graphics. SPSS, Inc. Chicago.

. 1996b. SYSTAT: new statistics. SPSS, Inc. Chicago.

Corresponding Editor: L. Stevens

\title{
GENETIC DIVERSITY AND CAPILLARIA HEPATICA (NEMATODA) PREVALENCE IN MICHIGAN DEER MOUSE POPULATIONS
}

\author{
SHAWN MEAGHER ${ }^{1}$ \\ Museum of Zoology and Department of Biology, University of Michigan, Ann Arbor, Michigan 48109
}

\begin{abstract}
There have been few field tests of the hypothesis that homozygous populations are prone to high levels of disease. I tested for a negative correlation between genetic diversity and parasitism by estimating the allozyme heterozygosity, population density, and proportion of individuals infected by Capillaria hepatica (Nematoda) in nine Michigan populations of deer mice (Peromyscus maniculatus). Parasite prevalence was correlated negatively with heterozygosity when the effects of density were held constant, but was not correlated with population density after controlling for the effects of genetic diversity. These data support the prediction that inbred populations will be more susceptible to parasite infestations.
\end{abstract}

Key words.-Allozyme heterozygosity, conservation biology, islands, parasitism, Peromyscus maniculatus, population density.

Received December 12, 1997. Accepted March 1, 1999.

Natural selection imposed by parasites may promote genetic variation in host populations (Haldane 1949; reprinted in Dronamraju 1990). Conversely, populations that lack variability may be more susceptible to parasite epidemics (O'Brien and Evermann 1988; Black 1992). However, there

\footnotetext{
${ }^{1}$ Present address: Biological Sciences, Western Illinois University, Macomb, Illinois 61455; E-mail: shawn_meagher@ccmail. wiu.edu.
}

are few data from animal populations with which to evaluate this proposition (Nunney and Campbell 1993). Here, I examine the idea that among-host genetic similarity will lead to enhanced disease spread by comparing the average allozyme heterozygosity and proportion of hosts infected by Capillaria hepatica (prevalence) among Michigan populations of deer mice (Peromyscus maniculatus gracilis). I also measured mouse population density to control for an ecological factor that can determine parasite transmission rates and levels of parasitism (Anderson and May 1979). 


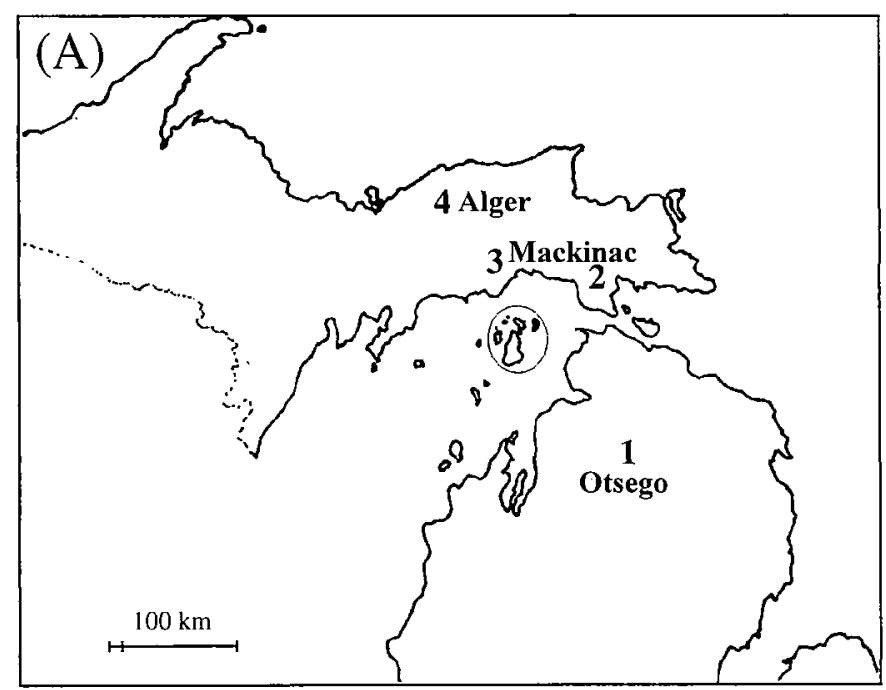

(B)

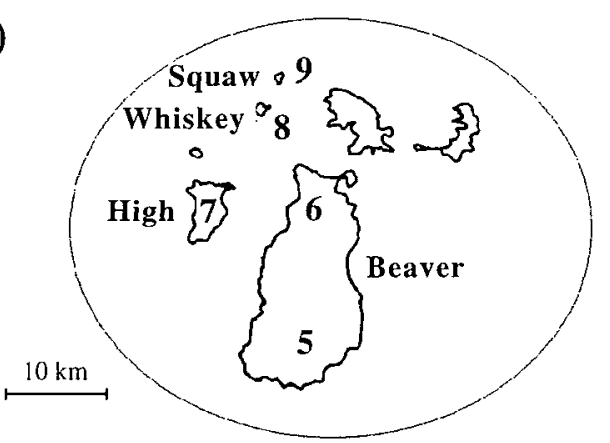

Frg. 1. Northern Michigan collection localities of Peromyscus maniculatus surveyed for genetic diversity and Capillaria hepatica infection. (A) Mainland localities. (B) Beaver Island archipelago (detail of A). Locality numbers match those in Table 3.

\section{Theoretical and Empirical Background}

Parasites, by definition, reduce host fitness (Scott 1988). If particular alleles make hosts resistant to some parasite species (or strains) but more vulnerable to others (Wakelin and Blackwell 1988), then parasites may promote genetic diversity in host populations through selection against homozygous genotypes (Bodmer 1972) or common alleles (Haldane 1949). We do not know whether the mechanisms of parasite resistance generally fit the assumptions of these models. The resistance of heterozygous hosts is not consistently greater than that of homozygous hosts (Apanius et al. 1997). Furthermore, parasite-driven, frequency-dependent selection has only recently been described in nature (Dybdahl and Lively 1998). Still, the idea that host-parasite coevolution produces genetically diverse hosts is supported by several types of evidence. These include: (1) extremely high levels of diversity in genes associated with the vertebrate immune response (Alt et al. 1987; Apanius et al. 1997); (2) the existence of genetic variation for parasite resistance within host species (Wakelin and Blackwell 1988); and (3) positive correlations between parasitism and host genetic diversity in the wild (Levin 1975; Lively 1987, 1992; Sherman et al. 1988; Nevo and Beiles 1992; Couch et al. 1993; Jokela and Lively 1995).

A corollary to the concept of parasite-driven genetic var- iation is the hypothesis that populations may be vulnerable to disease epidemics if they are not protected by genetic variation (O'Brien and Evermann 1988). Pathogens may spread more quickly in a genetically homogeneous population because there are few resistant heterozygotes or because most individuals share the same resistance genotype. In either case, populations with low levels of genetic diversity are predicted to display high proportions of infected individuals. Pathogens do spread more quickly in plant monocultures than in polycultures (Burdon and Jarosz 1990), but there is little support for this prediction in wild plant populations (Parker 1988; Roy 1993) and there are fewer relevant data for animals.

Evidence that genetic uniformity is dangerous to animal populations is provided by higher levels of parasitism in asexual than sexual populations (Lively et al. 1990; Moritz et al. 1991) and rapid parasite spread among artificial groups of closely related individuals (Shykoff and Schmid-Hempel 1991a,b). Disease outbreaks in endangered species provide dramatic examples (O'Brien et al. 1985; Thorne and Williams 1988), but without genetically variable host populations for comparison they furnish only circumstantial evidence that reduced diversity, and not another species-specific or ecological factor (such as crowded captive conditions), makes these populations disease prone. Few comparisons of parasitism have been made among natural populations that differ in levels of genetic variation (Lively 1987, 1992; Lively et al. 1990; Moritz et al. 1991; Nevo and Beiles 1992; Jokela and Lively 1995), and to date, no such comparison has been made among conspecific populations of a sexual vertebrate species.

\section{Materials And Methods}

Taxa

Peromyscus maniculatus is one of the most widely distributed and abundant mammals in North America (Hall 1981). Populations of $P$. maniculatus gracilis occur in both the Upper Peninsula (UP) and the northern Lower Peninsula (LP) of Michigan, as well as on the Beaver Island archipelago in northern Lake Michigan (Hatt et al. 1948; Fig. 1). These localities were free of glacial ice approximately 9500 years ago, followed shortly thereafter by the lake's lowest levels. At that time, the islands were connected to the LP. Around 4000 years ago, Lake Michigan reached its highest levels, and Whiskey, Squaw, and perhaps all but the highest points of High and Beaver Islands were submerged (Hatt et al. 1948; Dorr and Eschman 1970). Thus, island populations may be relicts from the LP or descended from overwater dispersers from the UP (Hatt et al. 1948).

The direct life cycle nematode, Capillaria hepatica, is a globally distributed liver parasite of mammals (Anderson 1992), whose transmission requires the death of infected hosts (reviewed in Spratt and Singleton 1986). This worm is common among Peromyscus species (Freeman and Wright 1960; Layne and Griffo 1961; Solomon and Handley 1971; Herman 1981) and is often the most prevalent macroscopic endoparasite in northern Michigan populations of P. maniculatus gracilis (Meagher, unpubl. data). Several features make this an excellent organism for testing for a negative 
TABlE 1. Enzyme abbreviations, names, Enzyme Commission (EC) numbers, and electrophoresis running buffers used in this study. Running buffers: A, $0.010 \mathrm{M}$ citrate-phosphate, $\mathrm{pH} 6.4 ; \mathrm{C}, 0.050 \mathrm{M}$ tris-maleate, $\mathrm{pH} 7.8 ; \mathrm{I}, 0.025 \mathrm{M}$ tris-glycine, $\mathrm{pH} 8.5$. Enzyme information and running buffer and stain recipes from Richardson et al. (1986). Abbreviations are used in the text and Table 2.

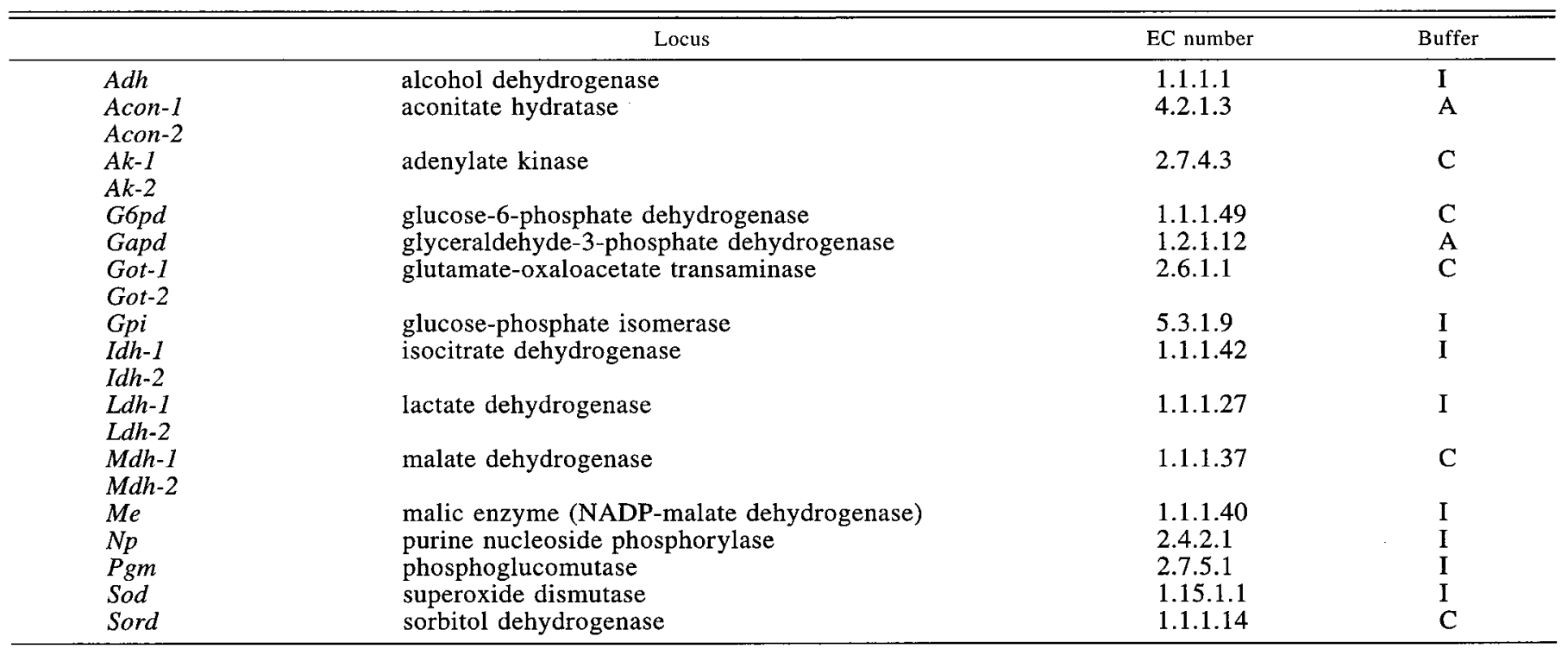

correlation between host genetic diversity and parasitism. First, it fits the definition of a parasite. Capillaria hepatica infestation causes liver cell death and cirrhosis (Luttermoser 1938). In laboratory mice, infection can reduce reproductive output (Singleton and Spratt 1986) or cause death (Luttermoser 1938; Spratt and Singleton 1986). In P. maniculatus, infection causes reduced liver protein synthesis, hepatomegaly, and splenomegaly (Meagher 1998), and may decrease metabolic performance (Meagher and $\mathrm{O}^{\prime}$ Connor, unpubl. $\mathrm{ms}$.). Resistance to $C$. hepatica is specific. Laboratory mice infected with $C$. hepatica display heightened immune responses on secondary exposure to $C$. hepatica (Luttermoser 1938; Solomon and Soulsby 1973), but not to challenges with a related nematode, Trichuris muris (Solomon and Soulsby 1973). Finally, resistance is probably genetic. The ability of C. hepatica to establish infections varies among laboratory mouse strains (Spratt and Singleton 1986), and mammal species (Freeman and Wright 1960; Meagher, unpubl. data).

\section{Localities}

Deer mice were trapped from nine Michigan localities (Fig. 1). These included one LP site in Otsego County and three UP sites: two from Mackinac County (east and west) in the eastern UP and one from Alger County in the north-central UP. Five sites were from four islands: two on Beaver Island and one site each on High Island, Whiskey Island, and Squaw Island. The LP, Mackinac County, and Beaver and High Island localities are characterized by second-growth sugar maple (Acer saccharum) forest with a relatively open understory. The UP Alger County site (Kingston Plains) is unique-it is a very open habitat characterized by lichens, grass, burned pine stumps and logs, and living red pines (Pinus resinosa) in small, widely spaced clumps. Whiskey and Squaw Islands have a sparse canopy of white birch (Betula papyrifera) and balsam fir (Abies balsamea). The three smallest islands have a dense understory of yew (Taxus canadensis).

\section{Mouse Population Density and Nematode Prevalence}

To provide consistent trapping effort at all localities, I set 100-150 traps approximately $15 \mathrm{~m}$ apart in straight trap lines (determined by compass). Host population density $(D)$ was estimated by trap success (number of animals caught per 100 traps set). All mice from a particular locality were caught in one or two nights of collecting and necropsied the day of capture. The presence of $C$. hepatica infection in each mouse was determined by gross liver examinations for yellowishwhite egg masses; more complex egg isolation procedures do not reveal hidden infections (Layne and Griffo 1961). The prevalence $(P)$ of $C$. hepatica for each locality was calculated as the number of hosts infected per number of hosts dissected (Margolis et al. 1982).

\section{Mouse Genetics}

At necropsy, liver tissues were frozen in liquid nitrogen and saved for genetic analyses. Enzyme electrophoresis of liver homogenates was performed on cellulose acetate (Helena Laboratories, Beaumont, TX) using the methods of Glenn and Smith (1993). After an initial survey of 38 enzyme systems using a variety of running conditions, mice were genotyped for 21 putative loci that could be scored reliably (Table 1). Average direct count heterozygosity $(H)$, Nei's unbiased genetic distance (Nei 1978), and a UPGMA dendrogram based on genetic distance were calculated with TFPGA (Miller 1997).

\section{Statistical Analyses}

Full and partial correlations (Spearman $\rho$ ) among the ranks of $H, D$, and $P$ were calculated with JMP (SAS Institute 1989). Critical values for partial correlation coefficients were taken from table D.21 of Zar (1974). 
TABLE 2. Allele frequencies for polymorphic loci among northern Michigan populations of Peromyscus maniculatus. Mainland population: Otsego County (Michigan's Lower Peninsula), Alger County, Mackinac County (east and west; MackE and MackW), all from Michigan's Upper Peninsula. Island populations: Beaver Island (south and north; BeavS and BeavN), High, Whiskey, and Squaw Islands. Loci names are in Table 1. Genotype sample sizes are in parentheses. The most cathodally migrating allele for each locus is designated "A." Polymorphic loci in each population are indicated in bold type.

\begin{tabular}{|c|c|c|c|c|c|c|c|c|c|c|}
\hline \multirow[b]{2}{*}{ Locus } & & \multicolumn{4}{|c|}{ Mainland } & \multicolumn{5}{|c|}{ Island } \\
\hline & & Otsego & MackE & MackW & Alger & Beavs & BeavN & High & Whiskey & Squaw \\
\hline$A d h$ & $\begin{array}{l}\text { A } \\
\text { B }\end{array}$ & $\begin{array}{l}0.00 \\
1.00 \\
(23)\end{array}$ & $\begin{array}{l}0.25 \\
0.75 \\
(14)\end{array}$ & $\begin{array}{l}0.00 \\
1.00 \\
(16)\end{array}$ & $\begin{array}{l}\mathbf{0 . 0 5} \\
\mathbf{0 . 9 5} \\
(20)\end{array}$ & $\begin{array}{l}\mathbf{0 . 0 3} \\
\mathbf{0 . 9 7} \\
(18)\end{array}$ & $\begin{array}{l}\mathbf{0 . 0 2} \\
\mathbf{0 . 9 8} \\
(20)\end{array}$ & $\begin{array}{l}\text { 0.02 } \\
\mathbf{0 . 9 8} \\
(20)\end{array}$ & $\begin{array}{l}\mathbf{0 . 0 2} \\
\mathbf{0 . 9 8} \\
(20)\end{array}$ & $\begin{array}{l}0.00 \\
1.00 \\
(21)\end{array}$ \\
\hline Acon-l & $\begin{array}{l}\text { A } \\
B\end{array}$ & $\begin{array}{l}\mathbf{0 . 6 1} \\
\mathbf{0 . 3 9} \\
(23)\end{array}$ & $\begin{array}{l}1.00 \\
0.00 \\
(10)\end{array}$ & $\begin{array}{l}\mathbf{0 . 8 5} \\
\mathbf{0 . 1 5} \\
(10)\end{array}$ & $\begin{array}{c}1.00 \\
0.00 \\
(9)\end{array}$ & $\begin{array}{c}1.00 \\
0.00 \\
(8)\end{array}$ & $\begin{array}{l}1.00 \\
0.00 \\
(11)\end{array}$ & $\begin{array}{c}1.00 \\
0.00 \\
(6)\end{array}$ & $\begin{array}{l}1.00 \\
0.00 \\
(15)\end{array}$ & $\begin{array}{c}1.00 \\
0.00 \\
(8)\end{array}$ \\
\hline Got-1 & $\begin{array}{l}\text { A } \\
\text { B }\end{array}$ & $\begin{array}{l}\mathbf{0 . 3 9} \\
\mathbf{0 . 6 1} \\
(22)\end{array}$ & $\begin{array}{l}\mathbf{0 . 9 7} \\
\mathbf{0 . 0 3} \\
(15)\end{array}$ & $\begin{array}{l}\mathbf{0 . 8 8} \\
\mathbf{0 . 1 2} \\
(16)\end{array}$ & $\begin{array}{l}\mathbf{0 . 8 0} \\
0.20 \\
(20)\end{array}$ & $\begin{array}{l}\mathbf{0 . 4 5} \\
0.55 \\
(19)\end{array}$ & $\begin{array}{l}\mathbf{0 . 5 0} \\
\mathbf{0 . 5 0} \\
(20)\end{array}$ & $\begin{array}{l}\mathbf{0 . 6 0} \\
\mathbf{0 . 4 0} \\
(20)\end{array}$ & $\begin{array}{l}1.00 \\
0.00 \\
(21)\end{array}$ & $\begin{array}{l}0.60 \\
0.40 \\
(21)\end{array}$ \\
\hline$G p i$ & $\begin{array}{l}\text { A } \\
\text { B }\end{array}$ & $\begin{array}{l}\mathbf{0 . 6 6} \\
0.34 \\
(22)\end{array}$ & $\begin{array}{l}1.00 \\
0.00 \\
(15)\end{array}$ & $\begin{array}{l}1.00 \\
0.00 \\
(16)\end{array}$ & $\begin{array}{l}1.00 \\
0.00 \\
(19)\end{array}$ & $\begin{array}{l}1.00 \\
0.00 \\
(18)\end{array}$ & $\begin{array}{l}1.00 \\
0.00 \\
(20)\end{array}$ & $\begin{array}{l}1.00 \\
0.00 \\
(20)\end{array}$ & $\begin{array}{l}1.00 \\
0.00 \\
(20)\end{array}$ & $\begin{array}{l}1.00 \\
0.00 \\
(21)\end{array}$ \\
\hline$N p$ & $\begin{array}{l}\text { A } \\
B \\
C \\
D \\
E\end{array}$ & $\begin{array}{l}0.00 \\
0.26 \\
0.26 \\
0.13 \\
0.33 \\
(23)\end{array}$ & $\begin{array}{l}\mathbf{0 . 0 0} \\
\mathbf{0 . 3 3} \\
\mathbf{0 . 2 7} \\
\mathbf{0 . 4 0} \\
\mathbf{0 . 0 0} \\
(15)\end{array}$ & $\begin{array}{l}0.00 \\
0.19 \\
0.50 \\
0.25 \\
0.06 \\
(16)\end{array}$ & $\begin{array}{l}0.00 \\
0.16 \\
0.63 \\
0.18 \\
0.02 \\
(19)\end{array}$ & $\begin{array}{l}\mathbf{0 . 0 3} \\
\mathbf{0 . 0 0} \\
\mathbf{0 . 4 7} \\
\mathbf{0 . 5 0} \\
\mathbf{0 . 0 0} \\
(18)\end{array}$ & $\begin{array}{l}0.00 \\
0.03 \\
0.53 \\
0.44 \\
0.00 \\
(19)\end{array}$ & $\begin{array}{l}\mathbf{0 . 2 2} \\
0.10 \\
0.68 \\
0.00 \\
0.00 \\
(20)\end{array}$ & $\begin{array}{l}\text { 0.00 } \\
0.34 \\
0.00 \\
0.16 \\
0.50 \\
(19)\end{array}$ & $\begin{array}{l}\mathbf{0 . 0 0} \\
\mathbf{0 . 0 0} \\
\mathbf{0 . 8 3} \\
\mathbf{0 . 0 0} \\
\mathbf{0 . 1 7} \\
(21)\end{array}$ \\
\hline Sod & $\begin{array}{l}\text { A } \\
\text { B }\end{array}$ & $\begin{array}{l}\mathbf{0 . 9 2} \\
\mathbf{0 . 0 8} \\
(23)\end{array}$ & $\begin{array}{l}\mathbf{0 . 9 7} \\
\mathbf{0 . 0 3} \\
(15)\end{array}$ & $\begin{array}{l}1.00 \\
0.00 \\
(16)\end{array}$ & $\begin{array}{l}1.00 \\
0.00 \\
(18)\end{array}$ & $\begin{array}{l}1.00 \\
0.00 \\
(19)\end{array}$ & $\begin{array}{l}1.00 \\
0.00 \\
(20)\end{array}$ & $\begin{array}{l}1.00 \\
0.00 \\
(20)\end{array}$ & $\begin{array}{l}1.00 \\
0.00 \\
(20)\end{array}$ & $\begin{array}{l}1.00 \\
0.00 \\
(20)\end{array}$ \\
\hline
\end{tabular}

\section{RESULTS}

Genetic Distance and Variation.-Thirteen loci were monomorphic in all populations (Acon-2, Ak-1, G6pd, Gapd, Got-2, Idh-2, Ldh-1, Ldh-2, Mdh-1, Mdh-2, Me, Pgm, and Sord), and eight were polymorphic in at least one locality (Table 2). Island populations were polymorphic only at loci that were variable in mainland localities (both UP and LP or UP only). Two loci were polymorphic in all mainland and nearly all island localities (Got-1,Np), two were polymorphic in the UP and at least one island ( $A d h, A k-2)$, and two were polymorphic in the LP only ( $G p i, I d h-1)$.

Genetic distances (Nei 1978) ranged from 0.000 to 0.039 (Table 3 ). Island populations were most similar genetically to UP populations (Fig. 2). Genetic distance was not correlated with geographic distance $\left(R^{2}=0.05\right.$, df $=34, F=$ $2.83, P=0.10$ ), due primarily to large genetic distances between Whiskey Island and geographically near islands (Table 3, Fig. 2). When distances involving Whiskey Island were excluded, genetic distance was positively correlated with geographic distance among the populations $\left(R^{2}=0.37\right.$, df $=26, F=16.79, P<0.001)$.

Average $H$ ranged from 0.035 to 0.126 (Table 4), which is similar to previous estimates for Peromyscus species (Kaufman and Kaufman 1989). Standard errors were large, and 95\% confidence intervals for all populations overlapped. $H$ was not correlated with island area $(r=0.74$, df $=3, P>0.10)$.

TABlE 3. Genetic distance (Nei 1978; below diagonal) and approximate geographic distance (km; above diagonal) for nine northern Michigan Peromyscus maniculatus populations.

\begin{tabular}{|c|c|c|c|c|c|c|c|c|c|c|}
\hline & Locality & (1) & (2) & (3) & (4) & (5) & (6) & (7) & (8) & (9) \\
\hline (1) & Otsego & - & 135 & 180 & 240 & 120 & 130 & 140 & 140 & 140 \\
\hline (2) & Mackinac E & 0.039 & - & 90 & 140 & 95 & 80 & 95 & 85 & 80 \\
\hline (3) & Mackinac W & 0.024 & 0.005 & - & 65 & 80 & 65 & 65 & 51 & 48 \\
\hline (4) & Alger & 0.029 & 0.006 & 0.000 & - & 135 & 120 & 110 & 105 & 105 \\
\hline (5) & Beaver I S & 0.022 & 0.019 & 0.011 & 0.001 & - & 15 & 18 & 22 & 25 \\
\hline (6) & Beaver I N & 0.022 & 0.016 & 0.008 & 0.006 & 0.000 & - & 10 & 12 & 12 \\
\hline (7) & High I & 0.025 & 0.018 & 0.007 & 0.003 & 0.009 & 0.006 & - & 8 & 12 \\
\hline (8) & Whiskey I & 0.035 & 0.011 & 0.012 & 0.018 & 0.032 & 0.029 & 0.028 & - & 3 \\
\hline (9) & Squaw I & 0.026 & 0.024 & 0.009 & 0.005 & 0.010 & 0.007 & 0.002 & 0.031 & 一 \\
\hline
\end{tabular}




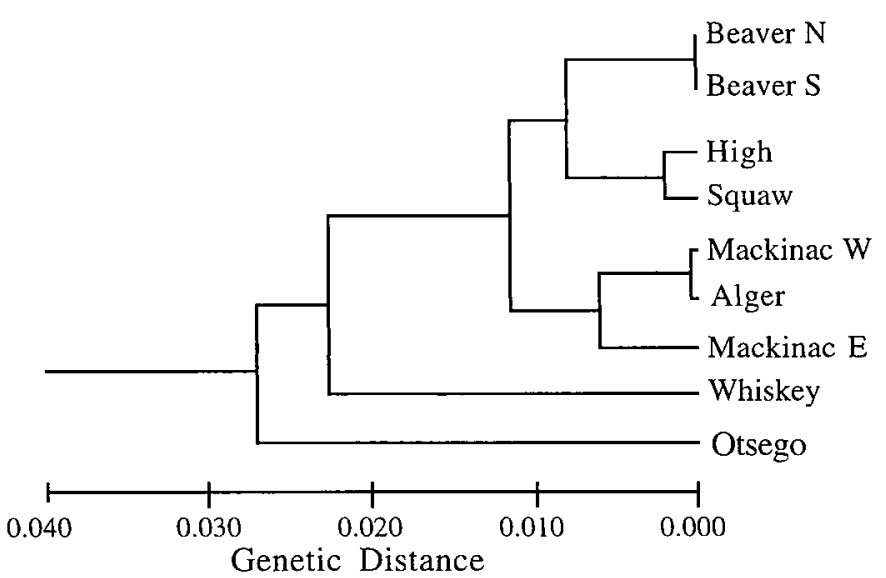

FIG. 2. UPGMA dendrogram for northern Michigan Peromyscus maniculatus populations. Dendrogram is based on Nei's unbiased genetic distance (Nei 1978) for 21 allozyme loci.

Population Density. $-D$ ranged from 0.11 to 0.66 (Table 4). Trap success was high in all localities except for the two eastern UP localities in Mackinac County. $D$ was consistently higher on islands than on the mainland, and there was a significant negative correlation between island area and $D(r$ $=-0.94, \mathrm{df}=3, P<0.01)$.

Prevalence. $-P$ ranged from 0.00 to 0.89 (Table 4). Capillaria hepatica was present in six of nine localities, including all three small islands, and half of the trapping sites from larger areas (one of two Beaver Island and two of four mainland sites). Beaver Island and mainland localities had low $P$. $P$ on Whiskey and Squaw Islands was higher and did not overlap these low $P$ localities. High Island $P$ was intermediate.

Correlations. $-P$ was correlated negatively with $H\left(\rho_{H P}=\right.$ $-0.90, n=9, P=0.001$; Fig. 3 ), and positively with $D$ ( $\rho_{D P}$ $=0.76, n=9, P=0.017$; Fig. 3 ). $H$ and $D$ were not significantly correlated $\left(\rho_{H D}=-0.63, n=9, P=0.067\right)$. The partial correlation between $H$ and $P$ was significant $\left(\rho_{H P . D}\right.$ $=-0.81, \mathrm{df}=7, P<0.01$ ), but that between $D$ and $P$ was $\operatorname{not}\left(\rho_{D P \cdot H}=0.43\right.$, df $\left.=7, P>0.20\right)$.

\section{DisCUSSION}

Genetic diversity and levels of parasitism may show a positive correlation among host populations if parasites them-

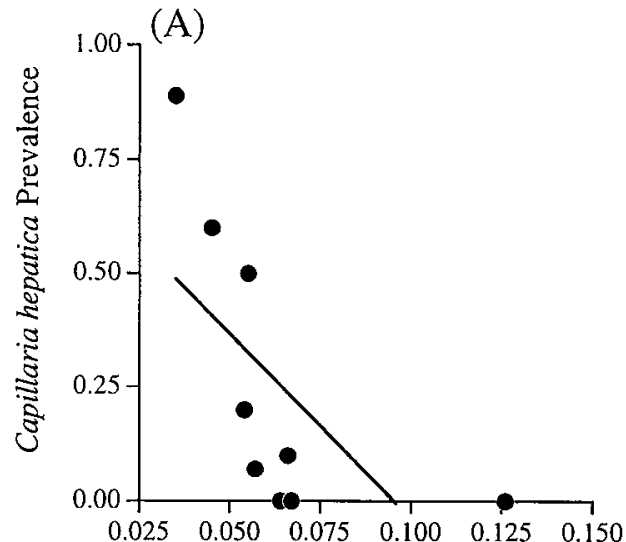

Allozyme Heterozygosity

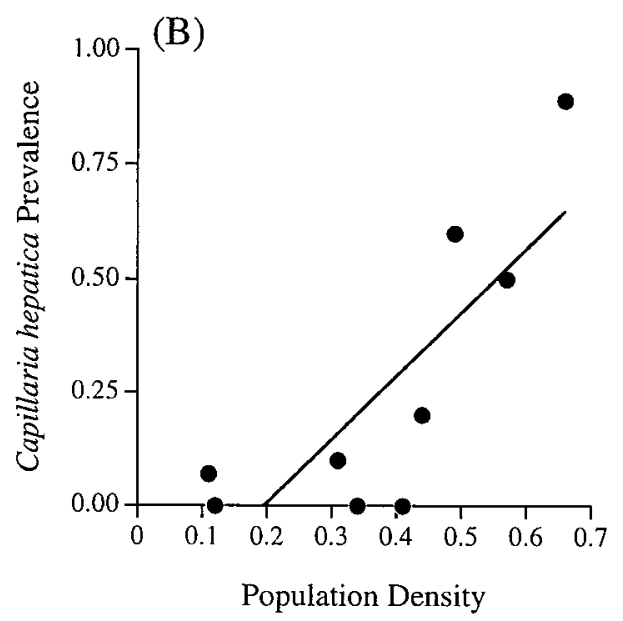

FIG. 3. Correlations of Capillaria hepatica prevalence with (A) average allozyme heterozygosity and (B) host population density among nine populations of Michigan Peromyscus maniculatus.

selves promote diversity (e.g., Lively 1987, 1992; Nevo and Beiles 1992; Couch et al. 1993; Jokela and Lively 1995). Diversity and parasitism may be correlated negatively, however, if parasites track levels of diversity that are determined by other factors (Johnson et al. 1997), including historical accidents. This study provides the first example of the latter prediction for sexual vertebrate populations.

Among Michigan $P$. maniculatus populations, I found a

Table 4. Summary of field data for northern Michigan Peromyscus maniculatus populations. Locality name, island area, mouse sample size $(n)$, average allozyme heterozygosity $(H)$, host population density $(D=$ number of mice/100 traps), and Capillaria hepatica prevalence $(P=$ number of infected hosts/number dissected hosts). Ninety-five percent confidence interval (CI) for $H$ is $1.96 \times \mathrm{SE}$ (Fowler et al. 1998 ) and those for $D$ and $P$ are from table IX of Sokal and Rohlf (1987). Locality numbers are given in Figure 1.

\begin{tabular}{llclll}
\hline \hline \multicolumn{1}{c}{ Locality } & Area $\left(\mathrm{km}^{2}\right)$ & $n$ & $H \pm \mathrm{SE}(\mathrm{CI})$ & $D(\mathrm{CI})$ \\
\hline (1) Otsego & LP mainland & 23 & $0.126 \pm 0.050(0.029-0.224)$ & $0.34(0.25-0.44)$ & $0.00(0.00-0.12)$ \\
(2) Mackinac E & UP mainland & 15 & $0.057 \pm 0.031(0.000-0.118)$ & $0.11(0.06-0.19)$ & $0.07(0.00-0.32)$ \\
(3) Mackinac W & UP mainland & 16 & $0.064 \pm 0.043(0.000-0.148)$ & $0.12(0.06-0.20)$ & $0.00(0.00-0.17)$ \\
(4) Alger & UP mainland & 20 & $0.066 \pm 0.035(0.000-0.134)$ & $0.31(0.22-0.41)$ & $0.10(0.01-0.32)$ \\
(5) Beaver I S & 151.24 & 19 & $0.067 \pm 0.045(0.000-0.154)$ & $0.41(0.31-0.51)$ & $0.00(0.00-0.14)$ \\
(6) Beaver I N & 151.24 & 20 & $0.054 \pm 0.035(0.000-0.123)$ & $0.44(0.34-0.57)$ & $0.20(0.06-0.44)$ \\
(7) High I & 15.02 & 20 & $0.055 \pm 0.030(0.000-0.114)$ & $0.57(0.47-0.67)$ & $0.50(0.27-0.72)$ \\
(8) Whiskey I & 0.51 & 21 & $0.035 \pm 0.033(0.000-0.099)$ & $0.66(0.56-0.75)$ & $0.89(0.68-0.99)$ \\
(9) Squaw I & 0.26 & 21 & $0.045 \pm 0.033(0.000-0.110)$ & $0.49(0.39-0.59)$ & $0.60(0.44-0.85)$ \\
\hline
\end{tabular}


significant negative correlation between allozyme heterozygosity and $C$. hepatica prevalence (Fig. 3). I also found a significant positive correlation between host population density and $C$. hepatica prevalence (Fig. 3), as has been found previously (Davis 1951; Freeman and Wright 1960; Childs et al. 1988; but see Layne 1968; Farhang-Azad 1977; Herman 1981). When both factors are considered simultaneously, only heterozygosity is correlated significantly with parasite prevalence.

Several points suggest that chance events have determined the pattern of genetic diversity in these populations. First, the UPGMA dendrogram (Fig. 2), and the fact that island populations share two of two alleles unique to UP populations ( $A d h-A$ and $A k-2-B$ ), and zero of two alleles unique to the LP ( $G p i-B$ and $I d h-A)$, suggest that the island populations are descended from UP ancestors. Because the islands have never had a land connection to the UP (Dorr and Eschman 1970), this implies founder events by UP colonists. Second, reduced diversity on the two smallest islands (Table 4), as well as island allele frequencies (Table 2) that are not correlated with geography (Table 3, Fig. 2), are consistent with small effective population sizes and genetic drift. Finally, genetic bottlenecks can inflate genetic distances (Nei 1987). Genetic distances on the order of 0.02 to 0.04 (Table 3 ) are expected after divergence times of 100,000 to 200,000 years (Nei 1987). Because these populations have existed for a maximum of 10,000 years (Dorr and Eschman 1970), after which genetic distances on the order of 0.002 are expected (Nei 1987), these large genetic distances probably reflect population bottlenecks associated with the colonization of these islands.

Historical accidents can also affect the prevalence of parasites in host populations. For instance, Otsego County mice, the most diverse in this study, may have a prevalence of 0.00 because $C$. hepatica has not colonized the LP (I have found no records of this parasite in northern lower Michigan). Excluding this extreme population does not change my results, however. When considered alone, both heterozygosity and density are correlated with prevalence $\left(\rho_{H P}=-0.87, n=8\right.$, $\left.P=0.003 ; \rho_{D P}=0.84, n=8, P=0.009\right)$, but only the partial correlation of heterozygosity with prevalence is significant $\left(\rho_{H P \cdot D}=-0.73\right.$, df $=6, P<0.05 ; \rho_{D P \cdot H}=0.42$, $\mathrm{df}=6, P>0.20)$.

My results are consistent with field experiments in which increased genetic diversity in sexual populations leads to decreased parasitism. Inbred sexual topminnows (Poeciliopsis monacha) displayed heavier trematode burdens than sympatric clonal individuals, until an introduction of new individuals (and genetic variation) into the sexual population reversed that pattern (Lively et al. 1990). Bumblebee (Bombus terrestris) colonies were manipulated to have high or low genetic diversity and then exposed to parasites under field conditions. High-diversity colonies displayed lower prevalences, average loads, and species diversity of parasitic protozoa, nematodes, and arthropods (Liersch and Schmid-Hempel 1998). Together, these studies indicate that reduced genetic diversity can lead to enhanced parasitism. These results have important conservation implications because increased susceptibility to disease is one factor that may reduce the survival of inbred individuals (Jimenez et al. 1994; Keller et al. 1994) or cause the extinction of entire inbred populations (Saccheri et al. 1998).

\section{ACKNOWLEDGMENTS}

I thank P. Myers for telling me about the islands; A. Powell for help getting to the islands and trapping mice; $B$. Vande Koppel, T. Crandall, and M. Paddock for logistical support and laboratory space at the University of Michigan Biological Station; and J. Gillingham for laboratory space at the Central Michigan Biological Station on Beaver Island. I thank Tracy Aviary for providing time to work on final revisions. This research was supported by funds from the Rackham School of Graduate Studies, Michigan Polar-Equator Club, University of Michigan Biological Station, and American Society of Mammalogists while I was supported by a National Science Foundation Predoctoral Fellowship. This paper was improved by comments from V. Apanius and M. Dybdahl.

\section{Literature Cited}

Alt, F. W., T. K. Blackwell, and G. D. Yancopoulos. 1987. Development of the primary antibody repertoire. Science 238:10791087.

Anderson, R. C. 1992. Nematode parasites of vertebrates: their development and transmission. CAB International, Oxon, U.K.

Anderson, R. M., and R. M. May. 1979. Population biology of infectious diseases. Part I. Nature 280:361-367.

Apanius, V., D. Penn, P. Slev, L. R. Ruff, and W. K. Potts. 1997. The nature of selection on the major histocompatibility complex. CRC Crit. Rev. Immunol. 17:179-224.

Black, F. L. 1992. Why did they die? Science 258:1739-1740.

Bodmer, W. 1972. Evolutionary significance of the HLA system. Nature 237:139-145.

Burdon, J. J., and A. M. Jarosz. 1990. Disease in mixed cultivars, composites, and natural plant populations: some epidemiological and evolutionary approaches. Pp. 215-228 in A. H. D. Brown, M. T. Clegg, A. L. Kahler, and B. S. Weir, eds. Plant population genetics, breeding, and genetic resources. Sinauer, Sunderland, MA.

Childs, J. E., G. E. Glass, and G. W. Korch, Jr. 1988. The comparative epizootiology of Capillaria hepatica in urban rodents from different habitats of Baltimore, Maryland. Can. J. Zool. 66:2769-2775.

Couch, L., D. W. Duszynski, and E. Nevo. 1993. Coccidia (Apicomplexa), genetic diversity, and environmental unpredictability of four chromosomal species of the subterranean superspecies Spalax ehrenbergi (mole-rat) in Israel. J. Parasitol. 79:181-189.

Davis, D. E. 1951. The relation between the level of population and the prevalence of Leptospira, Salmonella, and Capillaria hepatica in Norway rats. Ecology 32:465-468.

Dorr, J. A., and D. F. Eschman. 1970. Geology of Michigan. Univ. of Michigan Press, Ann Arbor.

Dronamraju, K., ed. 1990. Selected papers of J. B. S. Haldane. Garland Publishing, Inc., New York.

Dybdahl, M. F., and C. M. Lively. 1998. Host-parasite coevolution: evidence for rare advantage and time-lagged selection in a natural population. Evolution 52:1057-1066.

Farhang-Azad, A. 1977. Ecology of Capillaria hepatica (Bancroft 1893) (Nematoda). I. Dynamics of infection among Norway rat populations of the Baltimore Zoo, Baltimore, Maryland. J. Parasitol. 63:117-122.

Fowler, J., L. Cohen, and P. Jarvis. 1998. Practical statistics for field biology. 2d ed. Wiley, New York.

Freeman, R. S., and K. A. Wright. 1960. Factors concerned with the epizootiology of Capillaria hepatica (Bancroft, 1893) (Nematoda) in a population of Peromyscus maniculatus in Algonquin Park, Canada. J. Parasitol. 46:373-382.

Glenn, T. C., and D. R. Smith. 1993. Genetic variation and sub- 
specific relationships of Michigan elk (Cervus elaphus). J. Mammal. 74:782-792.

Haldane, J. B. S. 1949. Disease and evolution. La Ricerca Scientifica Suppl. 19:68-76.

Hall, E. R. 1981. The mammals of North America. Vol. 2. 2d ed. Wiley, New York.

Hatt, R. T., J. Van Tyne, L. C. Stuart, C. H. Pope, and A. B. Grobman. 1948. Island life: a study of the land vertebrates of the islands of eastern Lake Michigan. Cranbrook Press, Bloomfield Hills, MI.

Herman, T. B. 1981. Capillaria hepatica (Nematoda) in insular populations of the deer mouse Peromyscus maniculatus: cannibalism or competition for carcasses? Can. J. Zool. 59:776-784.

Jimenez, J. A., A. Hughes, G. Alaks, L. Graham, and R. C. Lacy. 1994. An experimental study of inbreeding depression in a natural habitat. Science 266:271-273.

Johnson, S. G., C. M. Lively, and S. J. Schrag. 1997. Evolution and ecological correlates of uniparental reproduction in freshwater snails. Pp. 263-291 in B. Streit, T. Städler, and C. M. Lively, eds. Evolutionary ecology of freshwater organisms: concepts and case studies. Birkhauser Verlag, Basel.

Jokela, J., and C. M. Lively. 1995. Parasites, sex and early reproduction in a mixed population of freshwater snails. Evolution 49:268-271.

Kaufman, D. W., and G. A. Kaufman. 1989. Population biology. Pp. 233-270 in G. L. Kirkland Jr. and J. N. Layne, eds. Advances in the study of Peromyscus (Rodentia). Texas Tech Univ. Press, Lubbock.

Keller, L. F., P. Arcese, J. M. N. Smith, W. M. Hochachka, and S. C. Stearns. 1994. Selection against inbred song sparrows during a natural population bottleneck. Nature 372:356-357.

Layne, J. N. 1968. Host and ecological relationships of the parasitic helminth Capillaria hepatica in Florida mammals. Zoologica 53: 107-122.

Layne, J. N., and J. V. Griffo. 1961. Incidence of Capillaria hepatica in populations of the Florida deer mouse, Peromyscus floridanus. J. Parasitol. 47:31-37.

Levin, D. A. 1975. Pest pressure and recombination systems in plants. Am. Nat. 109:437-451.

Liersch, S., and P. Schmid-Hempel. 1998. Genetic variation within social insect colonies reduces parasite load. Proc. R. Soc. Lond. B Biol. Sci. 265:221-225.

Lively, C. M. 1987. Evidence from a New Zealand snail for the maintenance of sex by parasitism. Nature 328:519-521.

-1992. Parthenogenesis in a freshwater snail: reproductive assurance versus parasitic release. Evolution 46:907-913.

Lively, C. M., C. Craddock, and R. C. Vrijenhoek. 1990. Red Queen hypothesis supported by parasitism in sexual and clonal fish. Nature 344:864-866.

Luttermoser, G. W. 1938. An experimental study of Capillaria hepatica in the rat and the mouse. Am. J. Hyg. 27:321-340.

Margolis, L., G. W. Esch, J. C. Holmes, A. M. Kuris, and G. A. Schad. 1982. The use of ecological terms in parasitology. J. Parasitol. 68:131-133.

Meagher, S. 1998. Physiological responses of deer mice (Peromyscus maniculatus) to infection with Capillaria hepatica. J. Parasitol. 84:1112-1118.

Miller, M. P. 1997. Tools for population genetic analysis (TFPGA) 1.3: Windows program for the analysis of allozyme and molecular population genetic data. Computer software distributed by author; Department of Biological Sciences, Northern Arizona University, Flagstaff.

Moritz, C., H. McCallum, S. Donnellan, and J. D. Roberts. 1991. Parasite loads in parthenogenetic and sexual lizards (Heteronotia binoei): support for the Red Queen hypothesis. Proc. R. Soc. Lond. B Biol. Sci. 244:145-149.

Nei, M. 1978. Estimation of average heterozygosity and genetic distance from a small number of individuals. Genetics 89:583590.

. 1987. Molecular evolutionary genetics. Columbia Univ. Press, New York.

Nevo, E., and A. Beiles. 1992. Selection for class II Mhc heterozygosity by parasites in subterranean mole rats. Experientia 48: $512-515$.

Nunney, L., and K. A. Campbell. 1993. Assessing minimum viable population size: demography meets population genetics. Trends Ecol. Evol. 8:234-239.

O'Brien, S. J., and J. F. Evermann. 1988. Interactive influence of infectious disease and genetic diversity in natural populations. Trends Ecol. Evol. 3:254-259.

O'Brien, S. J., M. E. Roelke, L. Marker, A. Newman, C. A. Winkler, D. Meltzer, L. Colly, J. F. Evermann, M. Bush, and D. E. Wildt. 1985. Genetic basis for species vulnerability in the cheetah. Science 227:1428-1434.

Parker, M. A. 1988. Genetic uniformity and disease resistance in a clonal plant. Am. Nat. 132:538-549.

Richardson, B. J., P. R. Baverstock, and M. Adams. 1986. Allozyme electrophoresis. Academic Press, New York.

Roy, B. A. 1993. Patterns of rust infection as a function of host genetic diversity and host density in natural populations of the apomictic crucifer, Arabis holbellii. Evolution 47:111-124.

Saccheri, I. J., M. Kuussaari, M. Kankare, P. Vikman, W. Fortelius, and I. Hanski. 1998. Inbreeding and extinction in a butterfly metapopulation. Nature 392:491-494.

SAS Institute. 1989. JMP user's guide. Vers. 2 of JMP. SAS Institute Inc., Cary, NC.

Scott, M. E. 1988. The impact of infection and disease on animal populations: implications for conservation biology. Conserv. Biol. 2:40-56.

Sherman, P. W., T. D. Seeley, and H. K. Reeve. 1988. Parasites, pathogens, and polyandry in social Hymenoptera. Am. Nat. 131: $602-610$.

Shykoff, J. A., and P. Schmid-Hempel. 1991a. Genetic relatedness and eusociality: parasite-mediated selection on the genetic composition of groups. Behav. Ecol. Sociobiol. 28:371-376.

. 1991b. Parasites and the advantage of genetic variability within social insect colonies. Proc. R. Soc. Lond. B Biol. Sci. 243:55-58.

Singleton, G. R., and D. M. Spratt. 1986. The effects of Capillaria hepatica (Nematoda) on natality and survival to weaning in BALB/c mice. Aust. J. Zool. 34:677-681.

Sokal, R. R., and F. J. Rohlf. 1987. Introduction to biostatistics. Freeman, New York.

Solomon, G. B., and C. O. Handley Jr. 1971. Capillaria hepatica in Appalachian mammals. J. Parasitol. 57:1142-1144.

Solomon, G. B., and E. J. L. Soulsby. 1973. Granuloma formation to Capillaria hepatica eggs. I. Descriptive definition. Exp. Parasitol. 33:458-467.

Spratt, D. M., and G. R. Singleton. 1986. Studies on the life cycle, infectivity, and clinical effects of Capillaria hepatica (Bancroft) (Nematoda) in mice, Mus musculus. Aust. J. Zool. 34:663-675.

Thorne, E. T., and E. S. Williams. 1988. Disease and endangered species: the black-footed ferret as a recent example. Conserv. Biol. 2:66-74.

Wakelin, D., and J. M. Blackwell. 1988. Genetics of resistance to bacterial and parasitic infection. Taylor and Francis, New York.

Zar, J. H. 1974. Biostatistical analysis. Prentice-Hall, Inc., Englewood Cliffs, NJ.

Corresponding Editor: C. Lively 